\title{
Viewshed Analysis for Improving the Effectiveness of Watchtowers, in the North of Mexico
}

\author{
Marín Pompa-García ", ${ }^{*}$ Raúl Solís-Moreno², Efraín Rodríguez-Téllez ${ }^{1}$, Alfredo Pinedo-Álvarez², \\ Diana Avila-Flores ${ }^{1}$, Ciro Hernández-Díaz ${ }^{2}$ and Efraín Velasco-Bautista ${ }^{3}$ \\ ${ }^{I}$ Facultad de Ciencias Forestales, UJED. Blvd. Durango y Papaloapan s/n. c.p. 34120. Col. Valle del Sur. Durango, \\ Dgo, México \\ ${ }^{2}$ Instituto de Silvicultura e Industria de la Madera, UJED. Blvd. del Guadiana, no. 501. c.p. 34160. Col. Valle del Sur. \\ Durango, Dgo, México \\ ${ }^{3}$ COMEF, INIFAP. Av. Progreso no. 5. c.p. 04010. Col. Barrio de Santa Catarina, Delegación Coyoacan, DF. México
}

\begin{abstract}
The forests in Mexico have been seriously affected by forest fires, and thus detection of fires from watchtowers is essential. The current numbers of watchtowers and effectiveness of their distribution is unknown. The aim of the present study was to determine the current and potential area visible from the watchtowers, and to propose a new network to maximize its effectiveness. Visibility analysis in ArcGis were developed by integrating a digital model of elevation and a vegetation cover map, to determine visibility on a surface from point to point along a given line of sight or across the entire surface in a viewshed. It was found that existing watchtowers provide an overall visibility effectiveness (43\%) very low compared with the recommended level. We suggest relocating one of the watchtowers and constructing another, which would increase the overall visibility effectiveness up to $81 \%$.
\end{abstract}

Keywords: Visibility analysis, watchtowers, forest fires.

\section{INTRODUCTION}

The Silvicultores Unidos de Guachochi (SUG) is an association of forest producers (mainly indigenous people) who are responsible for administering and managing their forest resources, which are important from ecological, social and economic standpoints.

Unfortunately, the Guachochi forests have been injured by forest fires, and are among the most seriously affected at the national level. During 2006 - 2007 period there were 1,683 fires and 29,065 hectares affected in the state of Chihuahua [1]. It is therefore essential to have effective strategies for preventing such disasters. In this sense, early detection of forest fires constitutes a key activity in fire management, since it has a direct impact on the effectiveness of firefighting and the extent of fire-related damage and effects [2].

Early detection of fire involves a series of activities, the aim of which is to discover and locate the starting point of the forest fire and to communicate this information to the central operating system. The availability of an efficient detection system in a forest firefighting programme guarantees that the damage caused by the fire and the cost of extinguishing the fire will be minimal [3].

At the worldwide level, several authors have recognized that modern scientific and technological procedures facilitate

Address correspondence to this author at the Facultad de ciencias forestales, UJED. Blvd. Durango y Papaloapan s/n. c.p. 34120. Col. Valle del Sur. Durango, Dgo, México; Tel/Fax: 01-618-1301096;

E-mail: mpgarcia@ujed.mx the development of techniques for detecting and monitoring forest fires, characterized by a combination of geographic information systems and spatial data on forest fires [4-6].

Visibility analysis is often used to determine areas that are visible from a specific location, and its applications range from the military field [7] to modelling of environmental changes $[8,9]$ generated an integrated geospatial system, which provides a series of software tools for the assessment of the propagation and combating of forest fires. The interface integrates GIS technologies under the same data environment that would serve as a useful tool for forest fire prevention, planning and management. In another study conducted by [10], developed a methodology for evaluating the effectiveness of fire detection in Portugal, and concluded that the current observation points were not sufficient. In order to address this [11], evaluated diverse geographical positions that maximize the visual cover, and concluded that high altitude areas should be included.

In the state of Chihuahua, fires are mainly detected from lookouts fixed on the ground, commonly known as "watchtowers". However, in Mexico, and specifically in Chihuahua, only one study has provided information about the area of visibility from the watchtowers in the state [12]. The conclusion reached in the latter study was that the current distribution is insufficient, and the authors suggested relocating the watchtowers to maximize the cover.

The Silvicultores Unidos de Guachochi currently have three watchtowers, although the appropriateness and effectiveness of their distribution -understood as the proportion of the area of the land to be protected that is visible- is not known. The aim of the present study was to 
determine the current and potential area of visibility from the detection towers, in the area managed by the SUG. It was assumed that the current geographical distribution of the watchtowers is insufficient to cover the forest land under consideration, and we propose an alternative spatial localization to maximize their effectiveness and that satisfies the condition of maximum area visible, with the smallest number of points to minimize the costs and efforts associated.

\section{MATERIALS AND METHODOLOGY}

The study was conducted in the area managed by the Silvicultores Unidos de Guachochi (an association of forest producers), corresponding to 30 communal areas of land and 1,000 small private properties, covering an area of 767,000 ha, in the southwest of the state of Chihuahua, between $26^{\circ} 38^{\prime}$ and $27^{\circ} 32^{\prime}$ 'North and 106 $30^{\prime}$ and 107 $54^{\prime}$ ' West (Fig. 1).

The study area is located in high range of the mountains where the topography is variable with irregular elevations and depressions, and climate is temperate with precipitation in summer, with percentage of winter precipitation ranging between 5 and 10 . The predominant vegetation is pure mass of pines with forest mixed with pine-evergreen oak, having patches of oak-pine. Silvicultores Unidos de Guachochi, is comprised of 30 ejidos (communal areas) and 1,000 small private properties, with a majority indigenous population.

In order to accomplish the stated objectives, a digital elevation model, of scale 1:50,000, was used in raster format of two bits/data and UTM coordinate system; the altitude values correspond to orthometric heights in whole units of meters and are relative to mean sea level, based on the North American Vertical Datum 1929. The model was acquired from the Instituto Nacional de Estadística Geografía e Informática (INEGI). The geographical coordinates and the physical characteristics of the fire detection towers in the forested land in the zone were determined (points 1, 2 and 3 in Fig. (1)). The geographical coordinates of three strategic points, of high altitude and which have traditionally been used in the study area to detect forest fires, were also recorded. The three points were proposed in this study as

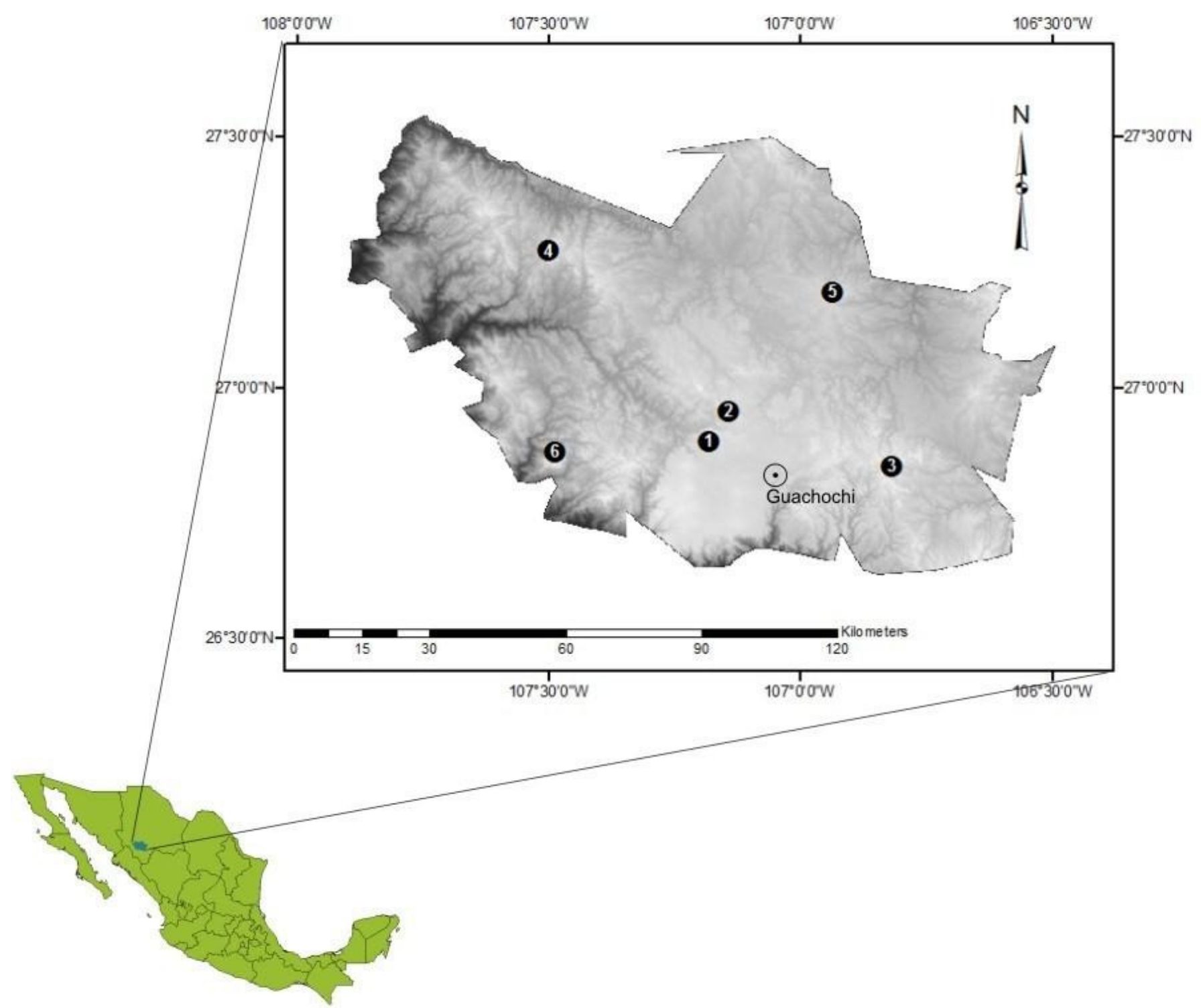

Fig. (1). Location of the area managed by the Silvicultores Unidos de Guachochi. 
possible locations for improving the effectiveness of forest fire detection: Cerro Samachique (2600 meters above sea level), Cerro el Chiwite (2621 masl) and Cerro Guirichique (2753 masl) (points 4, 5 and 6 respectively in Fig. 1). These peaks were chosen for good visibility and easy access offered.

In order to collect spatial information from field, a mobile mapping system was used. This consists of a GPS (Global Positioning System) coupled to a pocket computer with GPS applications for field cartography. Information from the 2000 national forest inventory was also obtained from SEMARNAT.

Once the spatial information about the six ground points was obtained, this was superimposed on the elevation digital model by use of the "viewshed" application in the topographical analysis of the ERDAS IMAGINE 8.4 software [13]; the "simultaneous observers function" technique was applied considering the criteria of altitude above sea level and above ground level (watchtower height) and visual cover of $360^{\circ}$, and with no restrictions regarding the maximum visualization range. The area of visibility was thus generated. The next step consisted of determining the combination of watchtower locations (points 1 to 6) that would maximize the area of visibility, with the smallest possible number of ground locations (watchtowers), as a restrictive condition.

Once a suitable visibility map was elaborated, this was combined with the national forest inventory cover and land use maps, in order to determine the types of vegetation visible from the watchtowers. This was achieved by use of the ArcGIS 9.2 program. The coordinate system corresponded to the geographical system, with WGS84 data.

\section{RESULTS}

There are three watchtowers in the study zone and three locations proposed; the installations and their characteristics are shown in Table $\mathbf{1}$, and the area of visibility covered by the towers is shown in Fig. (2).

The resulting raster maps synthesize the destruction potential and value loss for the whole area and are extremely useful to planners to understand where attention should be paid according to the duality fire potential and terrain value.

The combination that satisfied the condition of maximum area visible, with the smallest number of points (to minimize the costs associated with relocation or construction of new installations), corresponded to the relocation of the watchtower at Cerro de Cantiles (2) towards Cerro Chiwite (5), given the close vicinity of the former to the watchtower at Cerro Grande (1) and topography effects. Furthermore, we propose that an additional watchtower is built at Samachique (4), as this would maximize the area of visibility and level of effectiveness, predicted as $81 \%$ (Fig. 3), hereafter referred to as "potential effectiveness".

The classification of protected forest land is shown in Table 2, along with the results of the visibility analysis and the current and potential effectiveness:

\section{DISCUSSION}

The results indicated that the effectiveness of the current location of the network of forest fire detection towers in the study area is $43 \%$. In other words, $57 \%$ of the area is not directly visible to the observers. The visibility effectiveness recommended in the relevant literature is $80 \%$ [14]. Nevertheless, the current visibility in the study zone is not totally inefficient, taking into consideration the large area involved, as well as the indicator of effectiveness represented by the time of detection (10 minutes in 2003) reported by [15], which is consistent with the times reported in other similar studies $[3,11]$.

Taking into consideration the current location of the observation towers, the agricultural and grassland areas provide greatest visibility, because this type of land use usually corresponds to relatively flat topography. However, this is not true for low tropical forests, which on the contrary, provided the lowest percentage of visible area, since this type of vegetation is located on hillslopes, which range from 600 to 1600 meters above sea level and where very few watchtowers have been installed.

It is important to point out that the visibility effectiveness in the forest zone covered by pine-oak trees (and associated vegetation) is $32 \%$; this must be improved in the near future, through strategies that should attempt to maximize the level of visibility, since some 403,240 hectares remain unmonitored, i.e. $52 \%$ of the total area in the region, corresponding mainly to forest stands of high economic and environmental potential.

We therefore strongly recommend relocating the terrestrial detection systems in order to improve their effectiveness, although it should be emphasized that this system should also be reinforced by use of remote sensors to detect heat points and at-risk zones, and by use of ground and aerial patrols [16] and [17] have previously

Table 1. Forest fire Detection Towers in the Area Managed by the Silvicultores Unidos de Guachochi, Chihuahua

\begin{tabular}{|c|c|c|c|}
\hline Property & Location & Geographical Coordinates & Height (m) \\
\hline \hline (1) P.p. Cerro grande & Cerro Grande & $-107.18,26.89$ & 18 \\
\hline (2) Ejido Caborachi & Metatitos & $-106.82,26.84$ & 18 \\
\hline (3) Ejido Rocheachi & Cerro De Cantiles & $-107.14,26.95$ & 0 \\
\hline (4) Ejido Samachique & Cerro Samachique & $-108.02,27.22$ & 0 \\
\hline (5) Ejido Norogachi & Cerro Chiwite & $-106.40,26.51$ & 0 \\
\hline (6) P.p. Guirichique & Cerro Guirichique & $-107.49,26.87$ & \\
\hline
\end{tabular}




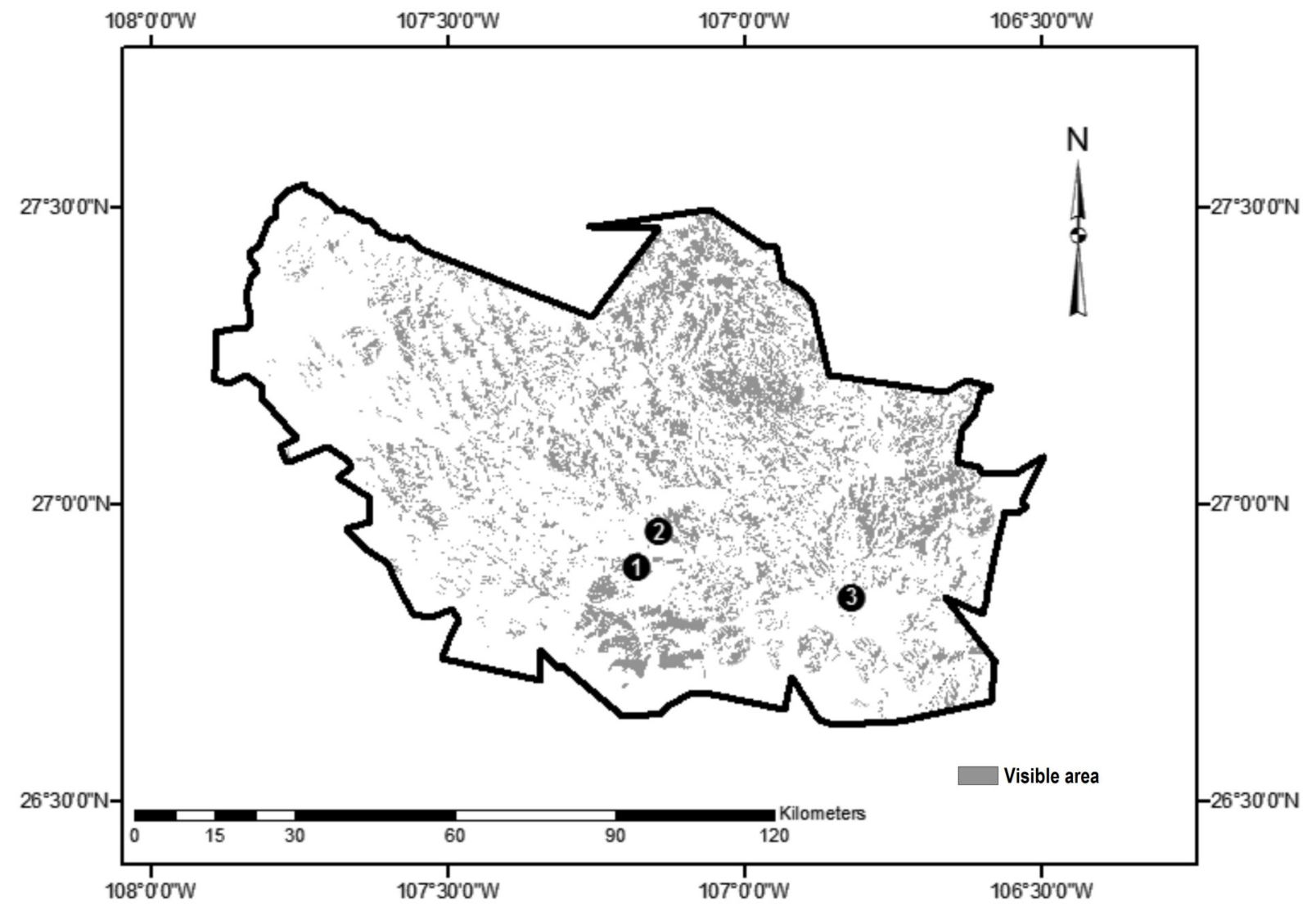

Fig. (2). Area currently visible from the forest fire watchtowers in the area managed by the Silvicultores Unidos de Guachochi, Chihuahua.

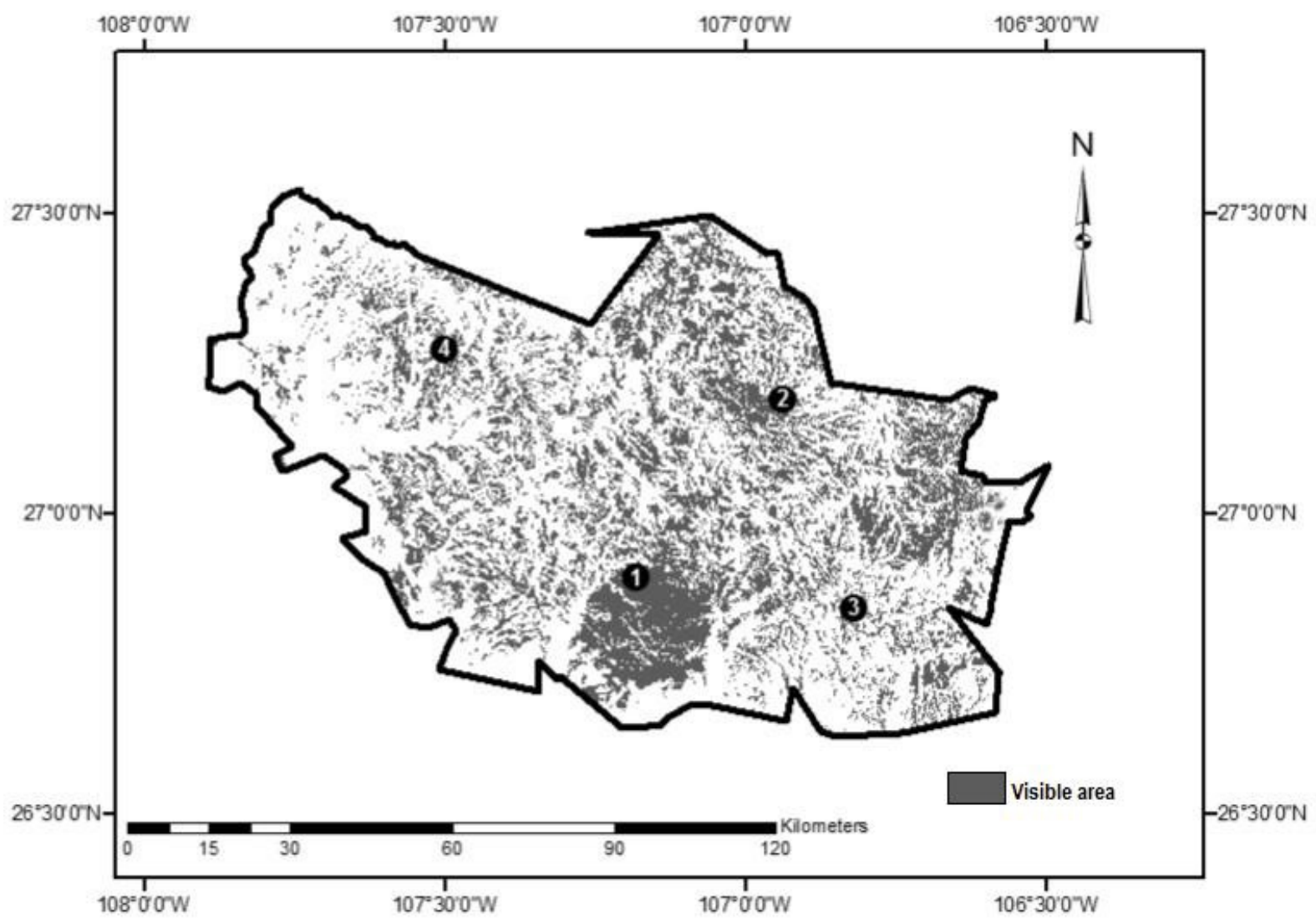

Fig. (3). Potential area of visibility achieved by relocating the forest fire watchtowers in the area managed by the Silvicultores Unidos de Guachochi, Chihuahua. 
Table 2. Current and Potential Visibility, in Relation to Type of Vegetation, of the Forest Fire Detection Towers in the Area of Influence of Silvicultores Unidos de Guachochi, Chihuahua

\begin{tabular}{|c|c|c|c|}
\hline Vegetation Type & Total Area in the Region (ha) & Current Visibility (\%) & Potential Visibility (\%) \\
\hline \hline Forest & 593000 & 32 & 88 \\
\hline Low tropical forest & 32000 & 10 & 10 \\
\hline Grassland and agricultural land & 142000 & 62 & 60 \\
\hline Total & 767000 & 43 & 81 \\
\hline
\end{tabular}

recommended the incorporation of environmental components such as vegetation and climatic conditions in predictive models. However, it has been shown that no system can achieve $100 \%$ effectiveness in the detection of forest fires at a reasonable cost [12].

Regardless of the high capacity of the specialized systems for visibility analysis, the working quality of the current watchtowers must also be considered. This includes the operating personnel and programmes, working equipment, information systems, etc. It must also be taken into account that the process of implementation is strongly affected by the available financial resources.

\section{CONCLUSION}

Visibility analysis by means of elevation digital models enabled reliable information to be obtained as regards the area of visibility throughout the forests in the zone of study.

Considering the proposed standard for the percentage area visible from forest fire watchtowers $(80 \%)$, it was concluded that the effectiveness of the current distribution $(43 \%)$ is not adequate, since some $57 \%$ of the area remains unmonitored. By relocating only the "Cerro de Cantiles" watchtower, located at point (2) and installing an additional tower, the observation effectiveness would rise to $81 \%$, and mainly favors pine-oak communities, the economic importance of which justifies the required investment. These results allow the minimization of time involved in the operations, such as fire detection, communication to base, forces preparation and start-up, air and ground transport, deployment of resources in the fire area and fire extinction and control. Planners are allowed to play with different distributions of bases, water points, lookouts and roads and see the effect in terms of efficiency of their new locations

An efficient fire detection system must also include the support of ground patrols, radio contact systems and remote sensing tools (to detect heat points).

\section{ACKNOWLEDGEMENTS}

We express our thanks to Dr. Carlos Alberto Ortíz Solorio of the Department of Soil Studies (Colegio de Posgraduados), for his valuable suggestions during the development of the present study.

\section{REFERENCES}

[1] CONAFOR. [homepage on the internet]. Reporte semanal de resultados de incendios forestales 2007. Coordinación de conservación y restauración. Gerencia de protección contra incendios forestales. [updated 2008 May 11; cited 2008 Jun 15]. Available from http://www.conafor.gob.mx/ portal/docs/subsecci ones/incendios_forestales/reporte_semanal2007.pdf

[2] Caballero D. Effect of random wind vectors in the final shape of fire spread simulation. Forest Ecology Manage 2006; 234 : 136.

[3] Mascaraque SA, Rodríguez FG, Hernández PE. Wildfires: 2007: Optimización de la ubicación de puestos de vigilancia de incendios forestales. Proceedings of the International Wildland Fire Conference; Seville, Spain. Palacio de exposiciones y congresos. May 13-17. 2007.

[4] Palacio PJ, Luna LG, Macías LM. Detección de incendios en México utilizando imágenes AVHRR (temporada 1998). Investigaciones Geográficas, Boletín del Instituto de Geografía de la UNAM 1999; 38: 7-14.

[5] Rego FC, and Catry FX. Wildfires: 2007: Modelling the effects of distance on the probability of fire detection from lookouts. Proceedings of the International Wildland Fire Conference. Seville. Spain. Palacio de exposiciones y congresos. May 13-17; 2007.

[6] Wu H, Pan M, Yao L, Luo B. A partition-based serial algorithm for generating viewshed on massive DEMs. Int J Geogr Inform Sci 2007; 21: 955-64.

[7] Franklin W, Ray C, Mehta S. Geometric algorithms for sitting of air defense missile batteries. Research Project for Battelle, Columbus Division, Contract Number DAAL03-86-D-0001, Delivery Order No. 2756. Scientific Services Program, 1994 [cited 2008 May 20]. Available from: http://www.ecse.rpi.edu/ wrf/ Research/p/tec_report.pdf

[8] Wang J, White K, Robinson J. Estimating surface net solar radiation by use of Landsat- $5 \mathrm{TM}$ and digital elevation models. Int J Remote Sensing 2000; 21: 31-43.

[9] Bonazountas M, Kallidromitou P, Kassomenos D, Passas N. Forest fire risk analysis. Human Ecol Risk Assess 2005; 11: 617-626.

[10] Catry XF, Rego CF, Santos AT, Almeida PJ, Relvas P. Wildfires: 2007: Forest Fires Prevention in Portugal - Using GIS to Help Improving Early Fire Detection Effectiveness. Proceedings of the International Wildland Fire Conference. Seville, Spain. Palacio de exposiciones y congresos. May 13-17, 2007.

[11] Almeida PJ, Relvas P, Silva L, Catry XF, Rego CF, Santos AT. Wildfires: 2007: Portuguese Lookout Towers Network Optimization Using Automatic Positioning Algorithms. Proceedings of the International Wildland Fire Conference. Seville, Spain. Palacio de exposiciones y congresos. May 13-17, 2007.

[12] Pompa GM, Treviño GE. Análisis de la cobertura visual de las torres de detección de incendios forestales en Chihuahua, México. Revista Chapingo. Serie ciencias forestales y del ambiente 2004; 10: $125-130$ 
[13] ERDAS Field Guide. $7^{\text {th }}$ ed. Atlanta, USA: Leica Geosystems GIS \& Mapping. 2003; p. 671.

[14] Julio AG. Diagnóstico y propuesta de lineamientos estratégicos en manejo del fuego para el Estado de Jalisco. Programa de desarrollo forestal de Jalisco. Proyecto manejo del fuego. Jalisco, México. 2000; p. 139.

[15] CONAFOR. Programa operativo 2004 de incendios forestales para el Estado de Chihuahua. Departamento de conservación y protección forestal de la Región VI "Río-Bravo". Chihuahua, México. 2004; p. 75.

[16] Bishop ID, Wherrett JR, Miller D. Using depth variables as predictors of visual quality. Environment Planning 2000; 27: 865875.

[17] Llobera M. Modeling visibility through vegetation. Int J Geogr Inform Sci 2007; 21: 799-810.

(C) Pompa-García et al.; Licensee Bentham Open.

This is an open access article licensed under the terms of the Creative Commons Attribution Non-Commercial License (http://creativecommons.org/licenses/by$\mathrm{nc} / 3.0 /$ ) which permits unrestricted, non-commercial use, distribution and reproduction in any medium, provided the work is properly cited. 